\title{
RUSSIAN FINANCIAL MARKET IN MAY 2015
}

\author{
E.Gorbatikov, E.Khudko
}

The MICEX Index averaged 1679 points as of the end of May 2015, down 1.5\% compared with that for the same period last year. It is the fall in crude oil prices that was responsible most for this value of the index. The MICEX daily average turnover contracted almost 20\% compared with that for Q1 2015, running at Rb 31,3bn. The Russian domestic corporate bond market saw a relatively positive trend despite the adverse external environment, complex situation in the economy and traditional seasonal downturn. Key market indices such as the volume and the index of corporate bond market, the weighted average yield rate (especially in the technological segment), investors' activity in the primary and secondary markets distinguished themselves by showing positive dynamics. Large bond issuers, despite having faced high financial risks during the recent few months, managed to successfully place their issuances of bonds with longer term until maturity. The situation with issuers' failure to honor their obligations to bondholders remained complex.

\section{The dynamics of Russian stock market basic structural indices}

The MICEX Index started to grow earlier in May and hit for the first time since March values beyond 1720 points at the end of the first week of the month ${ }^{1}$. The Index varied around 1700 points in the second week and then saw a gradual downtrend. The Index lost $1.55 \%$ while declining in the period between 27 April and 26 May 2015. The Index dynamics were chiefly governed by the movement of crude oil prices which on 5 March reached for the first time in 2015 values above $\$ 67$ per barrel, however by 26 May they slid to the value seen in the last month, i.e. down $1.33 \%$ from the value seen on 27 April.

Almost all of the blue chips showed a small negative ROE as of the end of May. Gazprom's shares, a leader in April, dropped lower in May than other blue chips, down $5.61 \%^{2}$. The cumulative return on the shares of Sberbank, Lukoil, Rosneft and the preferred shares of Surgutneftegaz varied around zero during the entire month. The shares of these companies saw a small negative ROE, varying within a range of $-1 \%$ and $-5 \%$ as of the month-end. Nontypical of the common trends was a positive trend for VTB's shares, up more than $35 \%$ as of the month-end. This may be attributed basically to the bank dividend policy ${ }^{3}$.

The top-3 leaders among highly liquid shares in terms of annual ROE remained the same from the

1 The presented herein data refer to the data on closing of the Exchange.

2 In the period between 27.04.2015 and 26.05.2015.

3 "VTB 24 which owned by VTB, will allot Rb 26,1bn as dividends for 2014. VTB 24's net profit in 2014 was running at Rb 31,5bn. As of the 2013 year-end, the bank also allotted Rb 19,7bn as dividends, which was almost the entire net profit". Available at http:// www.vedomosti.ru/finance/news/2015/05/21/kotirovki-aktsiivtb-virosli-do-maksimuma-s-nachala-2012-goda

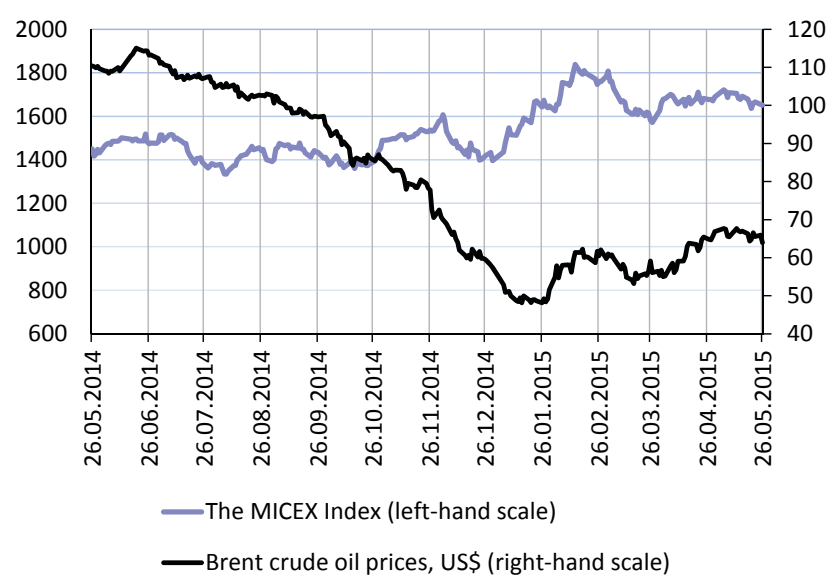

Source: RBC Quote, Finam.

Fig. 1. The dynamics of the MICEX Index and futures prices of Brent crude oil in the period between 26.05.2014 and 26.05.2015

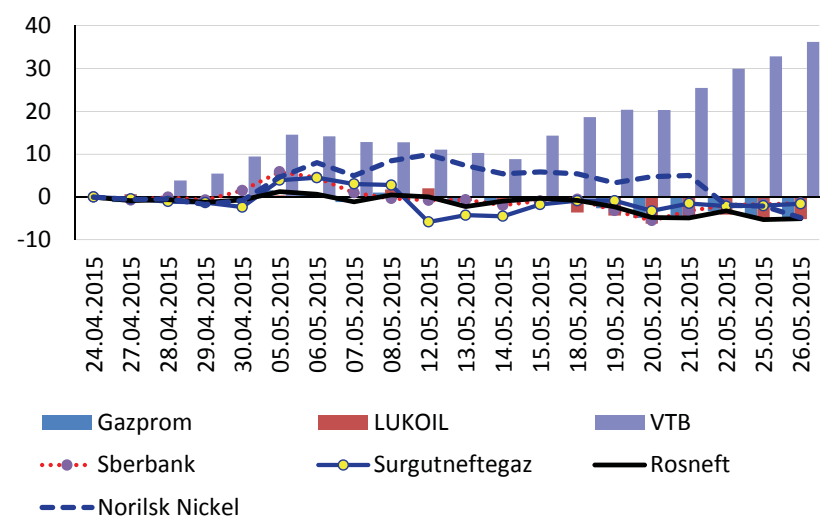

Source: RBC Quote, author's estimates.

Fig. 2. Growth rates of highly liquid Russian stocks in the Moscow Exchange in the period between 24 April and 26 May 2015

last month. However, VTB was ranked first as of the end of May, showing almost $70 \%$ of the annual return 
on equity ${ }^{1}$. The preferred shares of Surgutneftergaz's $(+47.65 \%)$ and Norilsk Nickel $(+42.05 \%)$ were ranked $2^{\text {nd }}$ and $3^{\text {rd }}$, respectively (they were ranked $1^{\text {st }}$ and $2^{\text {nd }}$ last month). Gazprom's year-end ROE was almost zero, while that of Sberbank was negative, with a $14.04 \%$ annual loss.

With the biggest contribution of VTB's shares, the financing companies index (up 9.38\%) was expectedly ranked $1^{\text {st }}$ among the MICEX Industrial Indices. Additionally, the machine-building sector index went up mostly due to Sollers's shares. The indices of energy and metal \& mining companies rolled back within two weeks following an uptrend in the first half of May, and their return on equity stood slightly less than $1 \%$. The indices of oil \& gas companies and consumer sector lost $3.09 \%$ and $4.37 \%$, respectively.

The Moscow Exchange's (MOEX) turnover in May saw a substantial decline, running at $\mathrm{Rb} 594,7 \mathrm{bn}$ in the period between 27 April and 26 May. This value was equal to $\mathrm{Rb} 31,3 \mathrm{bn}$ daily average turnover, i.e. down $17.4 \%$ compared with that for the previous month, $19.6 \%$ compared with that for Q1 2015, and 19.8\% compared with that for the corresponding period last year. The US\$ turnover declined more than $40 \%$ compared with that for May 2014.

Sberbank's shares were ranked 1st in May, accounting for $27.6 \%$ of the total turnover, down almost $4 \%$ compared with that for the previous month. Gazprom's shares were ranked 2 nd with a $12.4 \%$ turnover. VTB was ranked 3rd with a 9.4\% turnover (3.4\% in April), while the turnover in VTB's shares was almost twice that of Gazprom in the last week of the accounting period, and VTB was leading in terms of daily turnover on 25 and 26 May. The shares of Surgutneftegaz, Lukoil and Norilsk Nickel accounted for more than $7 \%$ of the MOEX turnover. Consequently, in May, the shares of Surgutneftegaz and Lukoil accounted for $40.0 \%$ of the MOEX turnover, while the four companies that followed the leaders accounted for another $32.4 \%$.

According to the data provided by the Emerging Portfolio Fund Research (EPFR), foundations investing in Russian shares saw further inflow $(\$ 202 \mathrm{~m})$ of investments in the second half of April, overrunning by more than $\$ 30 \mathrm{~m}$ the inflow in the first half of May which was characterized by capital outflows: while the net outflow in the first week was equal to a symbolic $\$ 0,3 \mathrm{~m}$, it was up to $\$ 45,9 \mathrm{~m}$ in the second week.

The MICEX total capitalization as of 26 May 2015 was running at $\mathrm{Rb} 27,41$ trillion (38.4\% of GDP), down $0.2 \%$ compared with that for the previous month. Like

1 The annual return on equity (ROE) is calculated based on changes in the price of shares, exclusive of dividends paid to shareholders following the annual and quarterly meetings of shareholders.

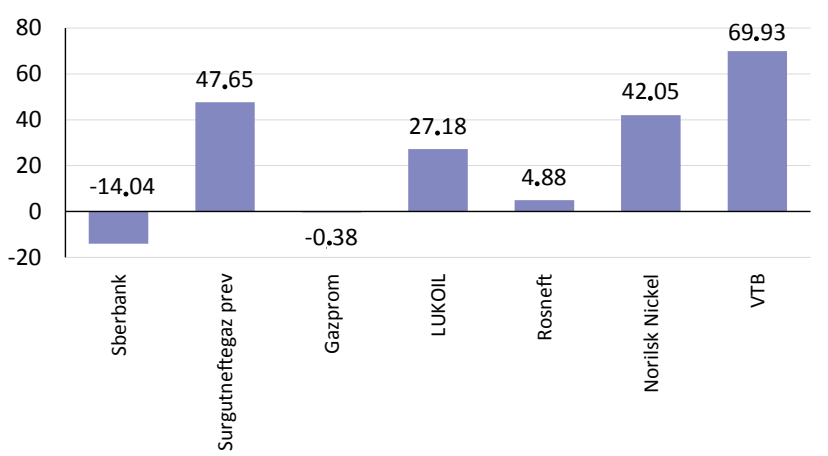

Source: RBC Quote, author's estimates.

Fig. 3. Growth rates of highly liquid Russian stocks in the Moscow Exchange in the period between 26.05.2014 and 26.05.2015

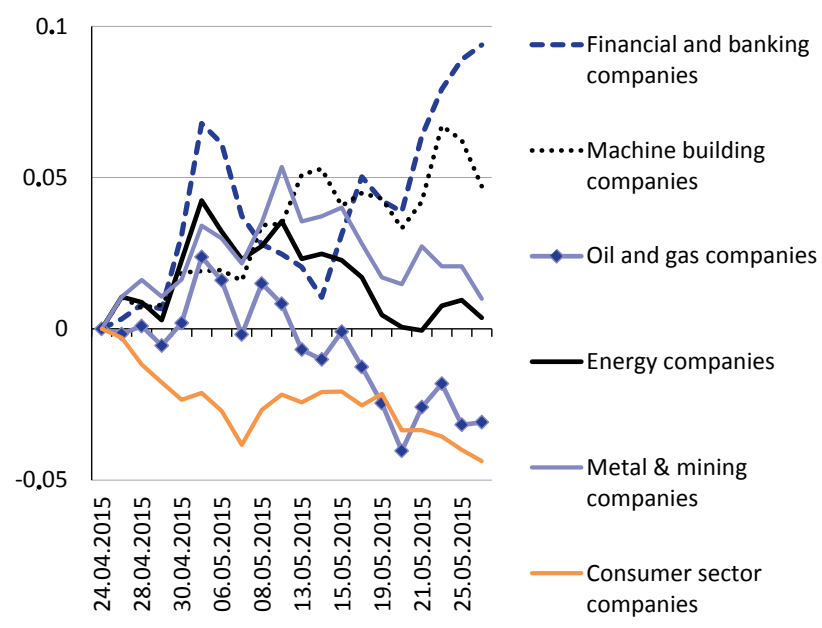

Source: RBC Quote, author's estimates.

Fig. 4. Growth rates in various sector stock indices in the Moscow Exchange in the period between 25 April and 26 May 2015

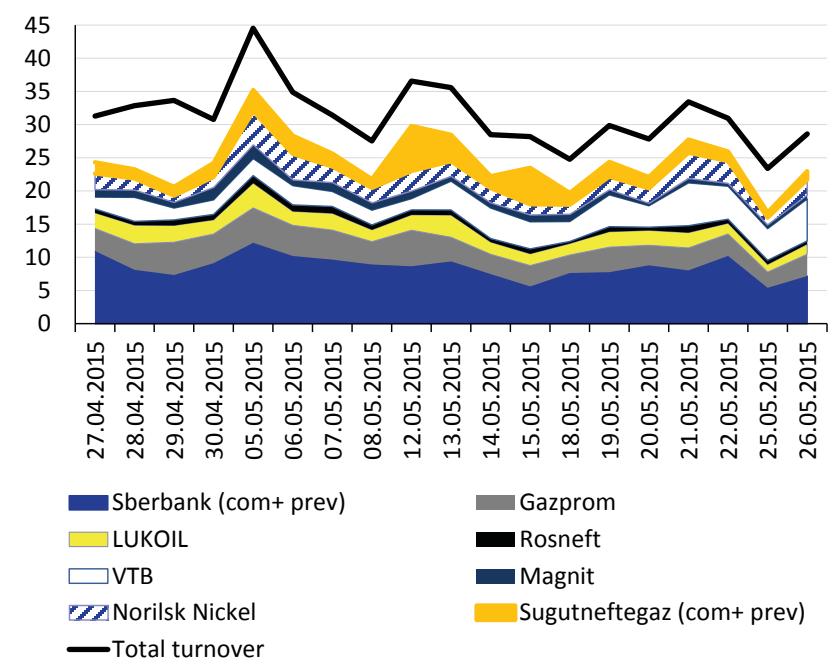

Source: RBC Quote, author's estimates.

Fig. 5. The Moscow Exchange trading volumes structure in the period between 27 April and 26 May 2015 
in the previous periods, almost half of the MICEX capitalization was accounted for by the oil \& gas industry and almost one third by the metal industry and the financial sector. A special emphasis should be placed on substantial changes in the capitalization structure, such as $1.3 \%$ increase in the financial sector and a $1.1 \%$ decline in the oil \& gas sector.

\section{Corporate bond market}

The Russian domestic corporate bond market volume (measured by the par value of outstanding securities denominated in the national currency, including those issued by non-residents) kept growing in May 2015 at a slowest pace. A new all-time high of $\mathrm{Rb} 7111,7 \mathrm{bn}$ was hit by the end of month, overrunning just $0.5 \%$ the value seen as of the end of April ${ }^{1}$. No substantial changes were seen in May in the number of either outstanding bond issuances (1086 corporate bond issuances in the national currency were registered versus 1085 issuances that took place as of the end of April) or bond issuers represented in the debt segment (360 issuers against 357 companies). Additionally, there were still 16 outstanding issuances of Russian US\$-denominated bonds (with a total value of more than $\$ 2,2 \mathrm{bn}$ ), and one outstanding JPYdenominated bond issuance.

Investors' activity in the secondary corporate bond market kept increasing despite the traditionally anticipated seasonal downtrend. For instance, the MOEX total trading volumes were running at $\mathrm{Rb} 151,7 \mathrm{bn}$ in the period between 23 April and 25 May 2015 (compared with that of $\mathrm{Rb} 123,7 \mathrm{bn}$ in the period between 24 March and 22 April 2015). On the contrary, the number of transactions in the period under review were down from record lows of the recent three months to the average annual of $24,000(33,500$ MOEX transactions were registered in the previous period) $)^{2}$, thereby showing that transactions were growing in value.

The Russian Corporate Bond Market Index (IFXCbonds) in May kept growing at a steady pace to increase substantially by the end of month, up 9.3 points (or $2.4 \%$ ) compared with that for the previous monthend. The positive dynamics of corporate bond average weighted yield also saw further uptrend, declining from $13.34 \%$ late in April to $12.25 \%$ by the end of the period under review, which was still below the central bank key interest rate, even after it was lowered on 5 May (Fig. 7) ${ }^{3}$. The corporate bond portfolio duration saw a timid decline for two consecutive months, although the value still remained more than 1.5 times its lows seen earlier in the year. As a result, the duration was 485 days

1 According to the data provided by Rusbonds Information Agency. 2 According to the data provided by Finam Investment Company.

3 According to the data provided by Cbonds Information Agency.

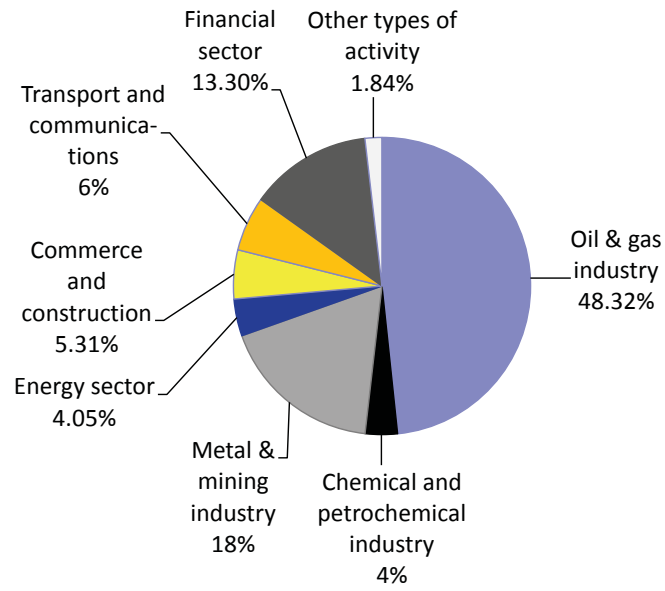

Source: The Moscow Exchange's official website, authors' estimates.

Fig. 6. Stock market capitalization structure by type of economic activity

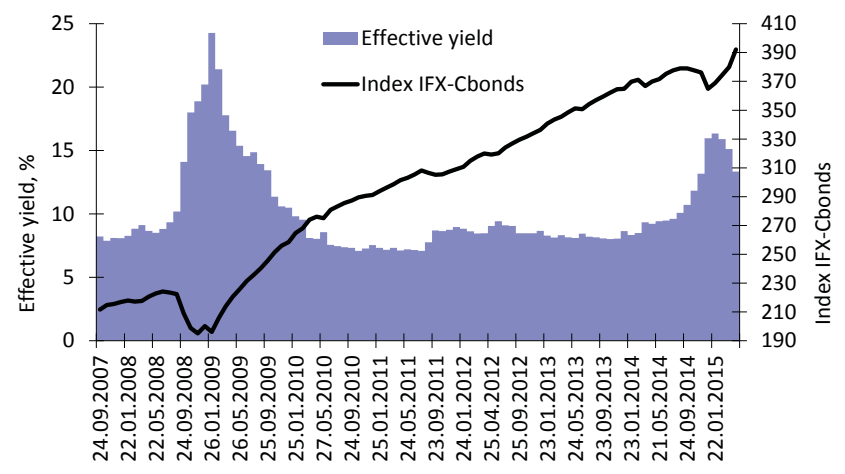

Source: according to the data provided by Cbonds Information Agency.

Fig. 7. The dynamics of Russian corporate bond market index and average weighted yield

as of the end of May 2015, 16 days less than that seen as of the end of last month.

The yield of debt securities kept slightly declining in the most liquid segment of the corporate bond market in the period under review. JSC VTB Bank, JSC Russian Agricultural Bank and Vnesheconombank saw most of the decline in terms of interest rate (more than 2 p.p.). It is worthwhile noting that the yield of certain bond issuances of some other financial institutions increased instead. In particular, JSC Gazprombank and JSC Agency for House Mortgage Lending experienced quite a growth of the interest (more than 3 p.p.) on their bond securities. On average, however, the yield on issuances of liquid securities in the financial sector was less than or equal to 0.6 p.p., whereas technology, production and energy companies showed a noticeable downtrend for their securities (by more than 1 p.p. on average $)^{4}$. It is worthwhile noting that investors showed special interest in financial companies, as well as there was a persistently strong demand for the

4 According to the data provided by Finam Investment Company. 
securities of energy operators, including regional ones, for three consecutive months.

Bond issuers' activity in terms of new fundraising remained very low despite a relatively stable situation in the bond market, which, however, can be explained by the seasonal factor. For instance, in the period between 23 April and 25 May 2015, only five bond issuers registered seven bond issuances with an aggregate par value of $\mathrm{Rb} 39,7 \mathrm{bn}$ (to compare, 15 series of bonds with a total value of $\mathrm{Rb} 35,0 \mathrm{bn}$ were registered in the period between 24 March and 22 April 2015) ${ }^{1}$. In May, like April, no large companies were found in the list of issuers, and almost all of the bond issuances were debut ones. The largest bond issuances were registered by LLC Two Capitals Highway, LLC GPB Finance and LLC Region-Invest. Another issuer registered a US\$-denominated bond issuance worth $\$ 50 \mathrm{~m}$. Moreover, other bond issuances denominated in foreign currencies are likely to take place in the market in the short run. For example, Vnesheconombank said it would raise $\$ 3$ bn to repay its external debt.

At the same time, investors' activity in the primary and secondary markets increased substantially, overrunning the monthly average values seen for the past few years. For instance, 18 issuers placed 21 debt issuances with an aggregate par value of $\mathrm{Rb} 176,7 \mathrm{bn}$ in the period between 23 April and 25 May 2015 (to compare, 32 series of bonds worth $\mathrm{Rb} 97,6 \mathrm{bn}$ were placed in the period between 24 March and 22 April 2015) (Fig. 8). Large bond issuances were placed by JSC Federal Grid Company, JSC Russian Railways (note that this company also placed large bond issuances in the previous two months), The State Company Russian Highways (Avtodor) $)^{2}$. Exchange-traded bonds accounted for almost half of the bond issuances placed in the period under review. Many bond issuers managed to raise funds with quite a long maturity: the Federal Grid Company issued bonds with a maturity of 35 years, Avtodor - 27 years, Russian Railways - 15 years, another four issuers raised funds with a maturity of 10 years. It is noteworthy that the yield of the bonds with long maturity issued by the Federal Grid Company is pegged to the inflation rate, which would be attractive for pension funds, according to experts.

1 According to the data provided by Rusbonds Information Agency. 2 According to the data provided by Rusbonds Information Agency.

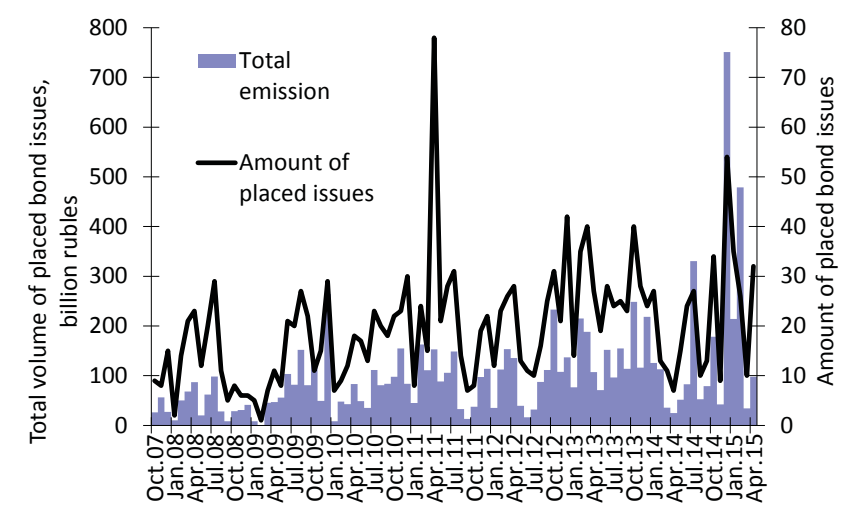

Source: According to the data provided by Rusbonds information agency.

Fig. 8. The dynamics of initial public offerings

of corporate bonds denominated in the national currency

In the period of late April to May, the Bank of Russia declared void two debut corporate bond issuances on the grounds of issuers not placing securities or revoking their fundraising plans, and hence cancelled registration of these issuances (in the previous period, three series of the bond issuances of a single issuer were declared void on the same grounds) ${ }^{3}$.

Eleven issuers were to redeem their 13 bond issuances with an aggregate par value of $\mathrm{Rb} 58,9 \mathrm{bn}$ in the period between 23 April and 25 May 2015. However, one issuer failed to redeem its securities and announced a technical default, while two issuers failed to honor their obligations when they fell due in the previous similar period. Five corporate bond issuances with a total volume of $\mathrm{Rb} 57,8 \mathrm{bn}$ are due to be redeemed in June $2015^{4}$.

The situation with issuers' failure to discharge their obligations to bondholders still remained complex: apart from a few technical defaults on coupon yield payment and redemption at par, three issuers announced a real default ${ }^{5}$ on the coupon yield payment and call (redemption of the debt to bondholders prior to maturity) - also, a few technical defaults and real defaults were announced in the previous similar period $^{6}$.

3 According to the data provided by the Bank of Russia.

4 According to the data provided by Rusbonds Information Agency.

5 In other words, when a bond issuer is unable to repay to bondholders even during the grace period.

6 According to the data provided by Rusbonds Information Agency. 